\title{
Quality of Financial Markets: Case Study from Emerging Market Economies
}

\author{
Henok Neguse Negash Prof. Hu Hongbing \\ School of Finance, Zhongnan University of Economics and Law, 182\#Nanhu Avenue Wuhan, 430073, China
}

\begin{abstract}
This paper investigates the quality aspect of financial markets in emerging economies and the key variables to achieve a desired level of quality. In our panel analysis, 17 major emerging countries were taken as a sample to analyze the relationship between quality of financial markets and the factors that affect quality. To measure the quality of financial markets, composite indexes were created that reflect the degree of financial market accessibility, depth, and efficiency. Besides, the indexes include the liquidity, diversity, and the institutional environment of financial markets in emerging economies. The variables include financial institutions access, depth, and efficiency on one set and on the other set financial market access, depth, and efficiency. The indexes and sub-indexes were extracted from the database of International Monetary Fund's International Financial Statistics office that holds global dataset of main indicators. Besides, World Development Indicators (WDI) indexes were employed to the research. We found that quality of financial markets and growth of financial development are highly correlated to each other. The disaggregated components of the quality measure suggest that it is the level of legal and institutional development along with accessibility, depth, and efficiency that affects the overall financial market growth. Hence, financial market quality. Our simple regressions show that the quality measures of financial markets have a positive output on higher quality of financial markets and growth of financial development. The causality of relationships between the components of financial markets and components of financial institutions were proven to have negative correlation showing that countries that pay more attention to the growth of financial institutions usually have less developed financial markets. This is mainly due to the fact that their markets are bank-based markets with highly regulated policies.
\end{abstract}

Keywords: Financial Market Quality, Emerging Economies, Financial Development, Financial market growth DOI: $10.7176 /$ RJFA/12-6-08

Publication date:March $31^{\text {st }} 2021$

\section{Introduction}

The integral role of financial markets in economic growth is undoubtedly significant. Existence of wellinfrastructure, liquid, and regulated financial markets promote alternative financing sources, investment opportunities, trading accessibility, risk management options, and others to private and publically owned firms and organizations, individuals, governments, profit and non-for-profit organizations. Existence of financial markets without proper accessibility and required liquidity might be irrelevant to different entities. Regardless of their size, organizations usually rely on financial institutions mainly financial markets to finance their capital requirements. Besides banks, financial markets play a vital role in providing financing options should these markets are fairly accessible and liquid.

Those markets are also important in attracting external capital inflows by providing different types of highly liquid financial assets varying from short-term overnight bonds to long-term bonds and shares. The capital inflow could trigger economic growth and progress. Given the overall situation of a country, FDIs (Foreign Direct Investment) are also the other means of capital attraction which would need accessibility of financial markets for their capital expenditures. The core point of the discussion is that these markets are very vital for economic growth by providing a framework for financing sources and investment alternatives. The soundness of an economy can be measured by the ability of the economy to create the required level of GDP, creation of new employment opportunities, money supply, level of inflation, and the financial system regulations and functions which also include the operations of financial markets and institutions. This would mean a healthy economic system that permits a balanced growth. The idea of economic soundness becomes adamant as it is the basics for building a healthy functional financial system. ${ }^{1}$ Besides, financial markets are also important in promoting new innovations of various financial instruments and implementation of new technologies by providing different financing and investment alternatives. Bagehot, in his late $19^{\text {th }}$ century book (1873, p 3-4) has clearly stated that the enormous economic success and development of England was due to its superiority in financial markets and institutions. This argument is true and only logical that London is the financial hub in all over Europe.

During the last decade the world has witnessed a global financial crisis which resulted in the slowdown of global economic growth. The financial markets got the big hit of the crisis and in turn has affected the economy. Financial instruments became almost absolute and toxic to be traded in the markets. Prices plunged, investors

${ }^{1}$ J. Greenwood, B.D.Smith/Journal of Economic Dynamics and Control 21 (1997) I45- I81 
rushed into pulling out their investments from the markets, governments were thrilled, and economies of most countries gotten in to recession. ${ }^{1}$ During the Asian financial crises, we all saw that a weak financial system not only makes a country open to international capital flows more vulnerable to crisis, but also exacerbates the costs of any financial crisis that does occur. The Asian crisis countries, Thailand, Indonesia, and Korea, vividly demonstrated that. The above stated points makes it clear that the financial system in general and financial markets in specific need a special attention to be taken care off by policy makers to avoid economic damages created due to lack of proper policies and infrastructure that determines financial markets.

The relevance theory states that stock exchanges are relevant to promote economic growth. This argument can be considered as strong point for developed countries that have well-functioning financial markets that are perfectly correlated with the economic situation. The signaling effect of the economic stages at different time affects the path of the stock markets in certain way. On the other hand, the outcomes of the financial markets will add up to the gross domestic product of a country by supporting different financial and economic sectors of a country. In addition, the stock markets are expected to control the amount of capital flows that would in turn help the economy to maintain a desired level of inflation. This particular feature is only achieved if the economy is doing a normal period (Perfect market theory) where resources including capital are distributed equally and fairly among the sectors. The achievement of a perfect market theory seems to be unrealistic considering the market, economic, and financial situation alongside many other factors.

The irrelevance theory argues on the contrary. The argument states the economic progress and stability is likely to enhance growth and help the financial sector to grow faster. Countries have been continuing whether or not they have financial markets. The theory originates from the pre-stock market creation theory and from the fact that there are many countries without financial markets in the world at the moment. It further stated that financial markets are dependable on the economic growth of a country. Therefore, according to the irrelevance theory, it is the growth of the economy that determines the quality of financial markets.

\section{Literature Review}

An area where there is less consensus is whether market-based financing or bank-based financing has a greater impact on development. A recent report focusing on Europe concluded that if Germany had had more marketbased finance (at a similar level to the United States) over the past 20 years, its GDP would now be approximately $2 \%$ higher while another study concluded that whether a country was bank-based or market based offered little explanation for differences in economic performance. Other researchers have suggested that it does matter and the answer depends on the specificities of the jurisdictions in question, referring to the quality of bureaucratic institutions, the strength and enforceability of the relevant legal frameworks, and the impact on shareholder protections, and even the underlying level of economic and financial development. There is also evidence that banks and markets interact, providing sometimes substitutable and sometimes complementary services at different stages of economic and financial development. The theoretical explanation for the link between the financial economy and the real economy is that financial market development promotes economic development by facilitating the mobilization of capital, and enabling risk sharing and risk transfer. Researchers are, however, still seeking to empirically isolate how stock exchanges (and other financial intermediaries) impact economic development. Some strands of research have suggested that markets enhance capital accumulation (see Bencivenga and Smith, 1991) while others focus on the impact on productivity (Levine and Zervos, 1998), more efficient resource allocation (Rajan and Zingales, 1998), and greater competition and innovation (Hsu, Tian and Zu, 2014).

A vast body of literature estimated the impact of financial development on economic growth, inequality, and stability. A typical empirical study proxy financial development with either one of two measures financial depth the ration of private credit to GDP or stock market capitalization to GDP. However, these indicators do not take into account the complex multidimensional nature of financial development. To correct this omission, the Financial Development Index was developed for the IMF staff discussion note "Rethinking Financial Deepening: Stability and Growth in Emerging Markets." It summarizes how developed financial institutions and financial markets are in terms of their depth (size and liquidity), access (ability of individuals and companies to access financial services), and efficiency (ability of institutions to provide financial services at low cost and with sustainable revenues and the level of activity of capital markets). The index database provides nine indices for over 180 countries with annual frequency from 1980 onwards.

Gerschenkorn (1962) argued that a developed financial system is a key condition for industrialization and that over the long sweep of history, the contribution of financial markets to economic growth has been significantly important (Stiglitz, 2010), pivotal (Schumpeter, 1912), or even too obvious for serious discussion (Miller, 1998). On the other hand, some researches have disagreed with idea of contribution of financial markets for economic growth. Robinson (1952) and Lucas (1988) have strongly argued that the importance of financial markets in economic development is highly exaggerated. Without proper rules and regulations, finance can grow excessively

\footnotetext{
${ }^{1}$ The Importance of Financial Markets in Economic Growth. Stanley Fischer, Citigroup, 2003
} 
causing a rent-seeking activity (Zingales, 2015), and even a powerful force for causing future financial crises (Schularick and Taylor, 2012; Mian and Sufi, 2014), with a potential of adverse implications for long-term growth and social welfare. Levine (2005) provides the closet semblance of a professional consensus by admitting that "We are far from definite answers to the question: Does finance cause growth, and if it does, how?" In a similar way, in the wake of the crisis, finance was openly blamed for the Great Recession making the public's trust to dissipate (Sapienza and Zingales, 2012), and policy makers started to warm up the idea that only through tight regulation of financial activity can a financial crisis of a similar magnitude be prevented from wreaking havoc on the real economy in the future.

According to the World Bank, global Gross Domestic Product (GDP) had grown from \$71.83 trillion in 2012 to approximately $\$ 74.91$ trillion in 2013. The United States accounted for over 22\% of global GDP in 2013, but the percentage has been declining over time owing to the emergence of the economies in India, China, Brazil, South Africa and other developing and emerging countries. As the economies of countries grow, mainly for the developing and emerging economies, financial markets and their role in the economic growth immensely grow parallel. Although there is a question on whether there exists a correlation between financial markets growth and economic growth the quality of the financial markets remains a determinant factor to the quality of the output of the contribution to the economic growth. Literatures have only summarized on the contribution of financial markets to economic growth in general undermining the quality of the markets and impact of the quality on economic growth.

In recent years, the issue of finance and financial system and its impact on the economy has gained more attention from scholars, politicians, etc. that only the establishment and existence of financial markets. This is mainly due to the reason that a less qualitative markets can cause financial crisis which can have the magnitude to make the economy to collapse and or leave the economy in a sustained recessionary period. There are certain evidences to support this argument. The 1997 Asian Currency Crisis is not long ago that left most of the far east Asian countries with severe inflation and deep recessions. We have witnessed the 2008 Global Financial Crisis that the world has suffered from forcing the US Federal Reserve to create "Too Big to Fail" banking and financial system. Many European countries faced recessionary economic periods. Governments stumble over their budgets. Countries including Iceland, Portugal, Spain, Italy, and Greece were forced to ask for a bailout from the rest of the other European economies and the European Central Bank (ECB). Greece mainly took the heat of the crisis forcing the government to default on its treasury bonds which was extra abnormal. The economy would have been collapsed had the European Central Bank and Germany were not willing to bailout the government under tight conditions of Austerity measurements to be taken by the Greece government. Leyhman Brothers only the second biggest investment bank in the world were forced to open a bankruptcy file although the company's statement showed a positive balance. The inability of this company to turn its assets in to cash made it worse and therefore the share values in the financial market shredded into the level of becoming "Toxic assets" in the financial market. Many other companies followed the same route and were collapsed due to the damage done in their shares in the financial markets. Therefore, it is very vital to understand the impact of financial markets in the overall markets situation and economic activity in order to determine whether these markets are adding value or diminishing the existing value. Sometimes the overflow of capital in these markets could also be a cause for price inflation. The market prices of the financial instruments traded could be misinterpreted and signal differently to the economy. The small-firm-effect is a good example of this. Small firms become overvalued due to seasonal variation in the US stock markets giving a negative signal to investors.

${ }^{1}$ A recent expanding literature establishes the importance of financial development to economic growth. The literature found that the size of the banking sector and the size and liquidity of stock markets are highly correlated with GDP per capita growth. When banks are liquid and of measurable size that made the required level of supply to the market and when the stock markets are of sizeable and liquid enough to act in a timely manner, this will significantly affect the economic growth which in turn will have an impact to GDP and GDP per capita growth. To this end there is a clear correlation between the two factors which mostly can be expressed in a positive movement. Moreover, a newly emerging evidence depicts that both the size of the banking sector development and stock market progress exerts a causal relationship and impact on economic growth. Recent researches have started to provide an empirical evidence that not only the existence of financial markets is enough for a sustainable economic growth. These researches are strongly in favor of existence of financial markets but mostly believe that these markets should be well-functioning markets that are strong enough to support the economy. Although the definition of well-functioning financial markets will be fully explained in the next chapters, it seems important for the author to mention some of the features of well-functioning financial markets as an introduction.

\footnotetext{
${ }^{1}$ For an overview over this literature see Levine (1997). See King and Levine (1993a,b) and Levine and Zervos (1998) for correlation and Levine, Loayza and Beck (1999), Beck, Levine and Loayza (1999), Neusser and Kugler (1998) and Rousseau and Wachtel (1998) for evidence on causality. Also, Demirgüç-Kunt and Maksimovic (1998) show that firms in countries with an active stock market and large banking sector grow faster than predicted by individual firm characteristics. Rajan and Zingales (1998) show that industries that rely more heavily on external finance grow faster in countries with better-developed financial system.
} 
Morgan Stanley Capital International (MSCI) for Emerging Markets provides a well-diversified index to measure the performance of equity markets of global emerging markets. The index captures mid and large caps across more than two dozen emerging market countries. The index is a float-adjusted market capitalization index and represents $13 \%$ of global market capitalization. The MSCI emerging markets index consists of 26 developing economies with 1,200 constituents including Argentina, Brazil, Chile, China, Colombia, Czech Republic, Egypt, Greece, Hungary, India, Indonesia, Korea, Malaysia, Mexico, Pakistan, Peru, Philippines, Poland, Qatar, Russia, Saudi Arabia, South Africa, Taiwan, Thailand, Turkey, and the United Arab Emirates. Since the inception of the index 1988, it has been growing rapidly and significantly from including only 10 countries to having more than two folds in just few decades indicating the financial market growth in emerging markets. It has achieved higher growth rates that it was used as a performance bench mark for mutual funds and market growth. However, due to the inherent political and monetary risks, emerging markets lately has been regarded as risky investments. Investors who turn to emerging markets should be prepared to receive volatile returns. While these returns may be significant, the opportunity for losses may be even larger. Emerging markets allow for diversity in an investor's portfolio, since they are less involved with already developed markets. This may reduce the overreaching risks associated with them. The following figure shows the allocation of MSCI index globally. The 26 countries included in the index are dispersed in 5 regions and the index has more than 1,100 constituents. The Asian markets held most of the index's constituents from the emerging markets. Most of the weights of the index are represented by emerging Asian markets mainly shown in China, Korea, and Taiwan financial markets. MSCI index has market classification criterion variables. The markets in MSCI index are classified in to developed, emerging, frontier, and standalone markets based on the preset indicators created to measure the development of a market. As an important component, the index uses investors' experience of market accessibility as its decision making criterion among other variables.

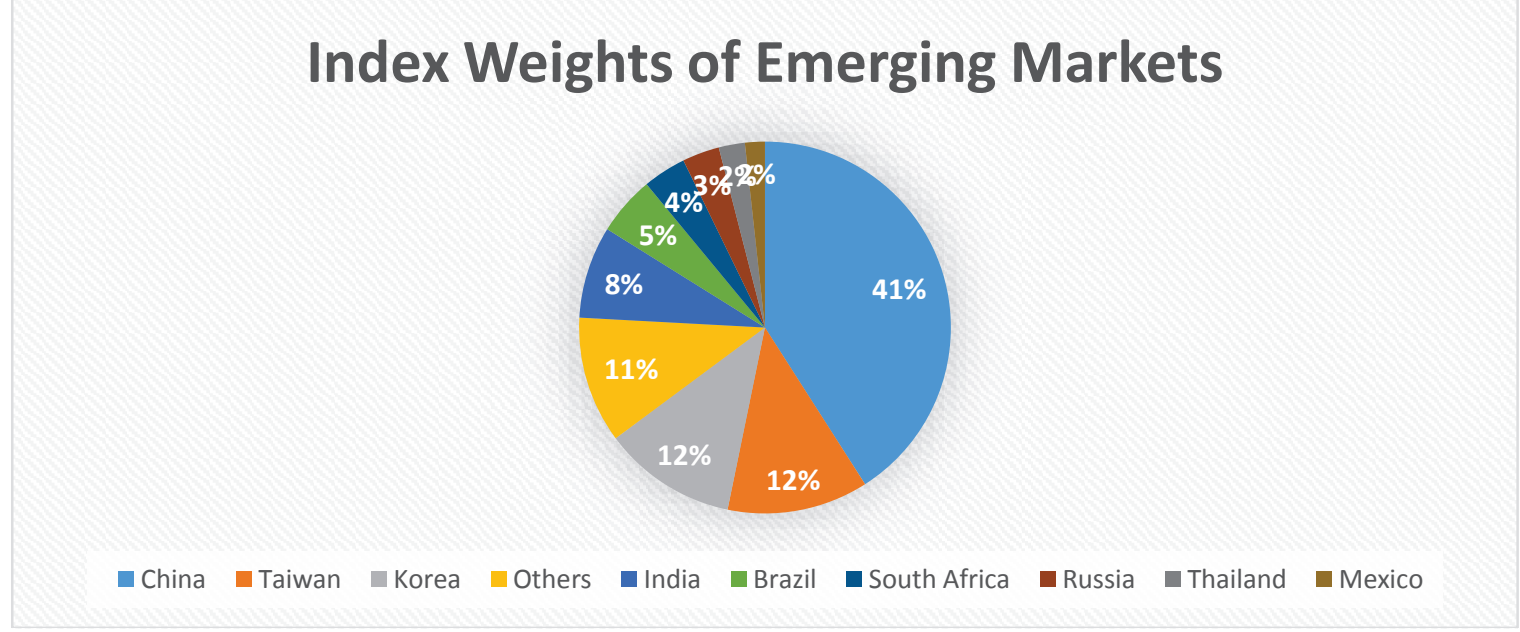

figure 1. MSCI index weights of emerging markets

As of June 30, 2020, Chinese markets dominate for most of the emerging market index weights with $41 \%$ proving the current high growth quality of its markets in the last two decades. The least weight in the index pie is given to Mexico with just nearly $2 \%$. Considering the economic turmoil that the country has been through the last few years, Mexico's weight could be a result that was expected beforehand. Beside that there has been an enormous shuffle in the country classification of the MSCI index with the least reclassification between the developed and emerging markets. For instance, Greece has been reclassified (downgraded) from the developed markets category to emerging markets category. When some countries were able to step up in the ladder from frontier markets to emerging markets, some has gone the reverse. The same shuffle has been observed between the levels frontier markets and standalone markets. Such classifications and reclassifications of countries are based on the annual general performance of their markets and the economic trends inherent that greatly affect the financial market wellbeing. According to the classifications made, investors are well-informed to make informed investment decision.

\section{Methodology and Data Description}

The dataset puts together 21 years of annual data between 1998 and 2018 for 17 emerging developing countries. It draws on a number of data sources: The World Bank FinStats (Feyen, Kibuuka, and Sourrouille, 2014), IMF's Financial Access Survey, Dealogic corporate debt database, and Bank for International Settlement (BIS) debt securities database. ${ }^{1} \mathrm{~A}$ vast body of literature estimates the impact of financial development on economic growth, inequality, and stability. A typical empirical study proxy's financial development with either one of two measures

\footnotetext{
${ }^{1}$ Financial Development Index Database, International Monetary Fund (IMF) strategy, Policy, and Review Department.
} 
of financial depth - the ratio of private credit to GDP or stock market capitalization to GDP. However, these indicators do not take into account the complex multidimensional nature of financial development. To correct this omission, Financial Development Index was developed for the International Monetary Fund (IMF) staff Discussion Note "Rethinking Financial Deepening: Stability and Growth in Emerging Markets." It summarizes how developed financial institutions and financial markets are terms of their depth (size and liquidity), access (ability of individuals and companies to access financial services), and efficiency (ability of institutions to provide financial services at low cost and with sustainable revenues and the level of activity of capital markets). The index database provides nine indicators for 17 emerging economies with annual frequency from 1998 to 2018.

The development of financial markets in developed, emerging, and developing countries follow similar trend although the applicability diverse immensely with regard to the economic growth and financial development of a country. In all the scenarios, however, the development and growth of financial markets is a function of mainly the financial development variable that includes different variables. Therefore, the basic understanding is that $F M G_{t}$ $=f\left(F D_{t-1}\right)$. The basic equation defines that the growth quality $(\mathrm{G})$ of financial markets at a given time $(\mathrm{t})$ is a direct function of the financial development at base zero time $\left(F D_{t-1}\right)$. Therefore, measuring financial development can give us a clear image about the growth quality of financial markets of countries. The research employs a 20 -year financial development index data of 17 emerging economies. The emerging economies are classified in to two based on their economic and financial progress. These are Big Emerging Markets (BEM) and Major Emerging Markets (MEM).

Generalized Method of Moments (GMM) will be applied to help us analyze the moments of economic and financial progress by constructing regression models. The generalized method of moments (GMM) is a method for constructing estimators, analogous to maximum likelihood (ML). GMM uses assumptions about specific moments of the random variables instead of assumptions about the entire distribution which makes it more robust than ML at the cost of some efficiency. The assumptions are called moment conditions. GMM generalizes the method of moment (MM) by allowing the number of moment conditions to be greater than the number of parameters. Using these extra moment conditions makes GMM more efficient that MM. when there are moment conditions than parameters, the estimator is said to be over-identified. GMM can efficiently combine the moment conditions when the estimator is over-identified.

To measure the degree of influence of financial development on quality of financial markets, we have formulated two indexes. These are Financial Markets Index and Financial Institutions Index. Each index consists three sub-indexes. Holding financial development (FD) as an independent variable, the first regression that include the sub-indexes of Financial Market Index is:

$\mathrm{FMQ}_{\mathrm{it}}=\alpha+\beta 1_{\mathrm{i}}+\mathrm{FD}_{\mathrm{it}}+\gamma_{\mathrm{i}} \mathrm{FIA}_{\mathrm{it}}+\gamma_{\mathrm{i}} \mathrm{FID}_{\mathrm{it}}+\gamma_{\mathrm{i}} \mathrm{FIE}_{\mathrm{it}}+\varepsilon \mathrm{i}$

To allow for possibility of partial adjustment, a dynamic log linear equation is specified below:

$\operatorname{lnFMQ}{ }_{i t}=\alpha+\beta 1_{i}+\operatorname{lnFD} D_{i t}+\gamma_{i} \operatorname{lnFIA}_{i t}+\gamma_{i} \operatorname{lnFID~}_{\text {it }}+\gamma_{\mathrm{i}} \operatorname{lnFIE}_{\mathrm{it}}+\varepsilon \mathrm{i}$

The indexes are expected to capture the depth of the financial development. This in turn will help us to explain how the quality of financial markets is in those countries. To control the uncaptured variables in the Financial Market Index, we will employ Financial Institutions Index. This will make the analysis to have a balanced output.

The first regression run resulted that the model is fit to explain the dependent variable - which in our case is the financial market growth. To identify whether financial development has a significant impact on financial market growth can be determined by regressing the level of financial markets access, depth, and efficiency. Other control variables are applied to show that financial markets are influenced by other micro and macro factors and non-financial factors including; GDP per capita, unemployment, interest rates, exchange rates, money supply, market elasticity, political risks, demographic setup, fiscal policies, and others. 
Table 1. Description of Variables and Data source

\begin{tabular}{|c|c|c|}
\hline Category & Indicator & Data Source \\
\hline FD & Financial Development & FinStats 2020 \\
\hline \multicolumn{3}{|c|}{ Financial Institutions Index } \\
\hline \multirow[t]{4}{*}{ Depth } & Private-sector credit to GDP & FinStats 2020 \\
\hline & Pension fund assets to GDP & FinStats 2020 \\
\hline & Mutual fund assets to GDP & FinStats 2020 \\
\hline & Insurance premiums, life and non-life to GDP & FinStats 2020 \\
\hline \multirow[t]{2}{*}{ Access } & Bank branches per 100,000 adults & FinStats 2020 \\
\hline & ATMs per 100,000 adults & IMF Financial Access survey \\
\hline \multirow[t]{6}{*}{ Efficiency } & Net interest margin & FinStats 2020 \\
\hline & Lending-deposit spread & FinStats 2020 \\
\hline & Non-interest income to total income & FinStats 2020 \\
\hline & Overhead costs to total assets & FinStats 2020 \\
\hline & Return on assets & FinStats 2020 \\
\hline & Return on equity & FinStats 2020 \\
\hline \multicolumn{3}{|c|}{ Financial Markets Index } \\
\hline \multirow[t]{5}{*}{ Depth } & Stock market capitalization to GDP & FinStats 2020 \\
\hline & Stocks traded to GDP & FinStats 2020 \\
\hline & International debt securities of government to GDP & BIS debt securities database \\
\hline & Total debt securities of financial corporations to GDP & Dealogic corporate debt database \\
\hline & $\begin{array}{l}\text { Total debt securities of non-financial corporations to } \\
\text { GDP }\end{array}$ & Dealogic corporate debt database \\
\hline \multirow[t]{2}{*}{ Access } & $\begin{array}{l}\% \text { of market capitalization outside of top } 10 \text { largest } \\
\text { companies }\end{array}$ & FinStats 2020 \\
\hline & $\begin{array}{l}\text { Total number of issuers of debt (domestic and } \\
\text { external, nonfinancial and financial corporations) }\end{array}$ & FinStats 2020 \\
\hline Efficiency & $\begin{array}{l}\begin{array}{l}\text { Stock market turnover ratio (stocks traded to } \\
\text { capitalization) }\end{array} \\
\end{array}$ & FinStats 2020 \\
\hline GDP per capita & Per capita & $\begin{array}{l}\text { World Development Indicators } \\
\text { (WDI) 2020. The World Bank }\end{array}$ \\
\hline $\begin{array}{l}\text { INF (consumer } \\
\text { price) }\end{array}$ & Annual percentage & $\begin{array}{l}\text { World Development Indicators } \\
\text { (WDI) 2020. The World Bank }\end{array}$ \\
\hline *INSQ & Institutional quality index & FinStats 2020 \\
\hline
\end{tabular}

* INSQ includes socioeconomic situations, government stability, investment profile, politics, corruption, internal and external conflicts, religions tensions, law and order, accountability, and bureaucratic quality.

The consistency of the GMM estimator mainly depends on the assumptions that the error terms do not exhibit second order serial correlation and that the instruments are valid. To check whether or not these assumptions hold, we conducted Sargan test for over-identification and serial correlation tests. Failure to reject the null hypothesis of these tests implies that the assumptions of the estimation hold. We also run Wald (joint-significance) test. we see the tests do not reject the econometric specification of the model. In all the GMM specifications, the test for first-order serial correlation rejects the null of no first-order serial correlation but does not reject the null of no second-order serial correlation. Thus, we conclude that the GMM estimators are valid and consistent because the Sargan test supports the validity of the instruments and from the second-order serial correlation test we cannot reject the hypothesis of the absence of second-order serial correlation. According to Baltagi et al. (2008) if lagged dependent variable is included in the model, all estimated beta coefficients represent short run effects. The long run effect can be derived by dividing each of the betas by 1 minus the coefficient of the lagged dependent variable. 
Table 2. Descriptive Statistics

\begin{tabular}{|c|r|r|r|}
\hline Variable & Coefficient & Std. Error & Prob. \\
\hline C & 0.031535 & 0.023607 & 0.2064 \\
\hline FD & 0.086565 & 0.236042 & 0.7202 \\
\hline FIA & 0.007313 & 0.110115 & 0.9481 \\
\hline FID & -0.124569 & 0.177692 & 0.4966 \\
\hline FIE & -0.124577 & 0.112004 & 0.2878 \\
\hline FI & 0.078647 & 0.239485 & 0.7483 \\
\hline FMA & 0.364618 & 0.083226 & 0.0009 \\
\hline FMD & 0.380957 & 0.056378 & 0.0000 \\
\hline FME & 0.311919 & 0.051822 & 0.0001 \\
\hline GDP per capita & 0.005717 & 0.039644 & 0.0008 \\
\hline INF & -0.030644 & 0.036540 & 0.0497 \\
\hline INSQ & 1.189900 & 0.029317 & 0.0078 \\
\hline
\end{tabular}

Financial development as key driver of the financial system (financial markets and institutions) was expected to score a positive correlation which it did as depicted in the table above. The tendency of the variable to affect the path and behavior of financial markets is inevitable. As financial development is a multi-faceted factor, when it grows eventually, financial markets also tend to show similar movement. Two variables in the analysis scored a negative coefficient with the dependent variable financial market which exactly was as expected. The tendency of financial markets is that it shows downward movement in the market when the depth and efficiency of other financial institutions increase. This is mainly due a shift in the investment behavior of investors, traders, and the population as a whole. A simpler scenario would be when commercial banks start to raise the deposit interest rate more than the marketing is offering other thing held equal, investments in the financial markets start to shrink eventually. This situation has the power to suppress the progress and growth of the financial markets. Therefore, the fact that the variables financial institutions depth (FID) and financial institutions efficiency (FIE) scored a negative coefficient of -0.124569 and -0.124577 respectively is a sign that these factors have a different signal and effect in the financial markets.

Table 3. Quality of Financial Markets in Emerging Economies (GMM Estimation)

Dependent Variable: Financial Market Quality (FMQ)

Method: Panel Generalized Method of Moments (GMM)

\begin{tabular}{|c|c|c|c|c|}
\hline \multirow{3}{*}{\multicolumn{2}{|c|}{ Variables }} & \multicolumn{3}{|c|}{ Dependent Variable: Financial Market Quality (FMQ) } \\
\hline & & \multicolumn{3}{|c|}{ Regression $\mathrm{N}^{\mathrm{O}}$. } \\
\hline & & $(1)$ & (2) & (3) \\
\hline \multicolumn{2}{|l|}{ Constant $(\alpha)$} & $\mid \begin{array}{l}0.0315^{* *} \\
(0.0236)\end{array}$ & $\begin{array}{r}0.3604 * * \\
(0.0805)\end{array}$ & $\begin{array}{c}-0.0314 * * * \\
(0.0820)\end{array}$ \\
\hline \multirow[t]{3}{*}{$\begin{array}{l}\text { Financial Market Quality } \\
\text { (FMQ) Indicators }\end{array}$} & FIA & $\begin{array}{r}0.0073 * * \\
(0.1101)\end{array}$ & & \\
\hline & FID & & $\begin{array}{c}-0.1245 * * \\
(0.1776)\end{array}$ & \\
\hline & FIE & & & $\begin{array}{c}-0.1245 * * * \\
(0.1120)\end{array}$ \\
\hline \multirow[t]{3}{*}{ Control variables } & GDP & $\begin{array}{c}0.0057 * * * \\
(0.0396)\end{array}$ & $\begin{array}{r}0.0565^{* *} \\
(0.1466)\end{array}$ & $\begin{array}{l}0.021736^{* *} \\
(0.12618)\end{array}$ \\
\hline & INF & $\begin{array}{r}-0.0306 * * * \\
(0.0365)\end{array}$ & $\begin{array}{r}-0.0042 * * * \\
(0.1030)\end{array}$ & $\begin{array}{l}-0.003157 * * * \\
(0.054674)\end{array}$ \\
\hline & INSQ & $\begin{array}{r}1.1899 * * * \\
(0.0293)\end{array}$ & $\begin{array}{r}0.3646^{* * *} \\
(0.0832) \\
\end{array}$ & $\begin{array}{r}0.3809 * * * \\
(0.0563) \\
\end{array}$ \\
\hline \multicolumn{2}{|c|}{ Total (unbalanced) observations } & 357 & 357 & 357 \\
\hline \multicolumn{2}{|l|}{$\mathrm{R}^{2}$} & 0.928274 & 0.925659 & 0.909220 \\
\hline \multicolumn{2}{|l|}{$\begin{array}{l}\text { Wald test of } \\
\text { probability }\end{array}$} & $(0.00)$ & $(0.00)$ & $(0.00)$ \\
\hline
\end{tabular}

Notes:

1. The regressions are estimated using dynamic panel GMM at first difference

2 . Figures in parentheses are standard errors

3. ***,**and * indicate statistical significance at $1 \%, 5 \%$, and $10 \%$ levels, respectively.

This also proves the situation in most of the developing countries in which the offer of deposit interest rates plays a vital role have a major impact on the growth of financial markets. One of the difficult economic situations 
is the trade-off between depth and efficiency of financial markets and depth and efficiency of financial institutions. However, economy stabilizes eventually according to the economic events. Financial market access, depth, and efficiency are interconnected to each other and have significant impact on the growth of financial markets. This in turn can determine the quality of the markets in the long run. The causal relationship between financial markets and the rest of the financial institutions depends on the economic scenarios both internally and globally. The anomalies that could basically affect growth and stability may differ across countries therefore it is necessary to assume these factors are shown in the data as endogenous effects.

Financial market growth inevitably has a significant role on financial development and economic growth. However, the quality of growth is another factor that has greater role and impact. The above analysis shows that the growth quality of financial markets can be measured using micro and macroeconomic factors both from financial markets point of view and the general financial development stand point as well. To analyze that, first, financial development was used as dependent variable to make a regression and see if the development in financial markets and financial institutions can explain the progress of it. In the following regressions where Financial Market (FM) was kept as dependent variable and see if other variables have an impact and cause on the quality and growth of financial markets, resulted in an expected outcome. Financial access (FA) scored a strong correlation with the dependent variable (financial market index). The integration between the two variables shows that when barriers of entry to the financial market are eliminated or lowered, quality tends to increase exponentially because accessibility of financial markets is one of the main pillars for growth. This depicts a negative correlation between quality of financial markets and intensity of barriers. As the intensity of entry barriers tightens the quality of financial markets significantly drops down because this policy decision signals greater risk and high cost to many potential investors. On the other hand, having extreme loosen entry policy can lead to high market concentration and can affect the market negatively. This can be said that many frauds, information asymmetry, and price fluctuations could hurt the market due to the lack of proper governance and governing policies.

\section{Conclusion}

Financial development is a multi-faceted component of an economy. The development of financial markets and financial institutions contributes to the growth of financial development which in turns plays a vital role in the overall economic growth and stability. The tradeoff required between the depth of financial institutions and financial markets indicates the direction and future trend of economic growth in a country. Researches have focused on the quantitative growth of financial markets in emerging economies. However, the quality of financial markets is also equally and significantly important factor to determine the financial development. Therefore, this research gave proper emphasis to quality aspect of financial markets. When the components of quality measures for financial markets and financial development were disaggregated, it showed that the differentiating point between the advanced economies from emerging and developing economies is that the level of legal and institutional development. Accessibility, depth, and efficiency of financial markets is also another factors that statistically scored significant figures to conclude the low quality of financial markets in emerging economies. Legal and institutional development grows eventually with time which makes it difficult for emerging and developing economies to rapidly built high-quality of financial markets that render similar services and scores parallel efficiency level to those in advanced economies. From what has been proved in the analysis, there is high interdependency between quality and growth of financial markets and financial development which shows that the more quality the financial markets attain in their growth the faster is the financial development. Attaining highquality financial markets however, is not achievable within short period of time. There are many exogenous factors that affect the quality of financial markets.

Previous researches on financial markets mainly focus on the quantitative aspects of the markets trying to measure the size and liquidity. Although there have been researches focusing on the quality of financial markets they were not as much. Therefore, this research was made to supplement and contribute to the researches that focus on the quality aspect of financial markets. Quality of financial markets was measured using major components including financial market access, depth, and efficiency. There exists two school of thoughts when it comes to the relationship between financial markets and financial development. The first school of thought states that the growth in financial development is a key factors to cause and stimulate the growth of financial markets. On the other hand, the second school of thought states that the growth of financial markets is a vital issue for the growth of financial development. A different economic theory takes a direction stating that there are economies with high financial development yet low growth of financial markets. This research is a supplement to the first school of thought that states the growth in financial development is a key factors to cause and stimulate the growth of financial markets. This is mainly due to the fact that many emerging and developing economies lack proper creation of financial system. Once the financial system which is composed of the depository and non-depository institutions are wellestablished and strengthened, establishment of financial markets are inevitable. Therefore, there is an interchangeable influence between quality of financial markets and growth of financial development. To put it in other words, the growth in financial development has a significant role in the quality of financial markets and in 
turn the quality of financial markets will help the stability of financial development and economic growth. Focusing mainly on quality of financial markets does not make the research anything less of dealing with growth and stability factors of financial markets. Therefore, when dealing with the quality of financial markets, the concept of growth is included within. As mentioned above, the theories and models on quality of financial markets mainly are designed to help grow the advanced economies. From economic stand point, this phenomenon might be obvious that many advanced economies tend to have an upper hand and thereby controlling the slow growth of developing and emerging economies. Therefore, the emerging countries need new financial and economic theories that specifically addresses their need to have well-established financial system in general and high-quality financial markets.

\section{References}

Jeremy Greenwood and Bruce D. Smith, "Financial markets in development, and the development of financial markets" Journal of Economic Dynamics and Control 21 (1997)145-181.

Levine Ross, Zervos Sara, "Stock Markets, Banks, and Economic Growth" Journal of American Economic Review volume $88,1998 / 02 / 01$

Levine Ross, "Bank-Based or Market-Based Financial System: Which one is better?" Journal of Financial Intermediation, vol. 11, issue 4, 398-428, 2002

Valerie R. Bencivenga; Bruce D. Smith, "Financial Intermediation and Endogenous Growth" The Review of Economic Studies, Vol. 58, No. 2. (Apr., 1991), pp. 195-209

Raghuram G. Rajan \& Luigi Zingales, "Financial Dependence and Growth" Economic Review, Vol. 88, no. 3 (1998): 559-586, Sept 1, 1996

Jeremy Greenwood, Bruce D. Smith, "Financial markets in development, and the development of financial markets" Journal of Economic Dynamics and Control 21 (1997) 145-181

Afangideh, U. J., Garbobiya, T. S., Umar, F. B., \& Usman, N. (2020). "The impact of inflation on financial sector development: Evidence from Nigeria" International Journal of Economics and Finance, 12(2), 1-56

Bencivenga, Valerie R. and Bruce D. Smith, 1991, "Financial intermediation and endogenous growth", Review of Economic Studies 58, 195-209.

Hsu, Tian and $\mathrm{Zu}$, "Financial Developemtn and Innovation: Cross-Country Evidence" Journal of Financial Economics vol. 112, issue 1, 116-135, 2014

Baltagi, B. H., Demetriades, P. O., \& Law, S. H. (2009). Financial development and openness: Evidence from panel data. Journal of Development Economics, 89(2), 285-296

E. Han Kim and Vijay Singal, "Stock Market Openings: Experience of Emerging Economies" The Journal of Business, Vol. 73, No. 1 (January 2000), pp. 25-66

Rousseau, P.L., and P. Wachtel (2000), "Equity Markets and Growth: Cross-country Evidence on Timing and Outcomes, 1980-1995," Journal of Banking and Finance, 24, 1933-1957.

Guglielmo Maria Caporale \& Peter G. A Howells \& Alaa M. Soliman, "Stock Market Development and Economic Growth: The Causal Linkage," Journal of Economic Development, Chung-Ang Unviersity, Department of Economics, vol. 29(1), pages 33-50, June 2004

Huang, Ho-Chuan and Chih-Chuan Yeh, "Level, structure, and volatility of financial development and inflation targeting", Journal of Empirical Finance, 44, (C), 108-124, 2017

Valpy Fitz Gerald, "Finance and Growth in Developing Countries: Sound Principles and Unreliable Evidence" QEH Working Papers, Queen Elizabeth House, University of Oxford

Castaneda, Gonzalo, "Economic growth and concentrated ownership in stock markets," Journal of Economic Behavior and Organization, Elsevier, vol. 59(2) pages 249-286, February 2006

Ratna Sahay, Martin Čihák, Papa N’Diaye, Adolfo Barajas, Ran Bi, Diana Ayala, Yuan Gao, Annette Kyobe, Lam Nguyen, Christian Saborowski, Katsiaryna Svirydzenka, and Seyed Reza Yousefi, "Rethinking Financial Deepening: Stability and Growth in Emerging Markets" IMF Staff Discussion Note SDN/15/08, May 2015

Katsiaryna Svirydzenka, "Introducing a New Broad-based Index of Financial Development" IMF Working Paper WP/16/5, January 2016

Charles Amo Yartey and Charles Komla Adjasi Stock Market Development in Sub-Saharan Africa: Critical Issues and Challenges. IMF working paper WP/07/209

Alonso-Borrego, C., and M. Arellano (1999), "Symmetrically Normalized Instrumental Variable Estimation Using Panel Data," Journal of Business and Economic Statistics, 17, 36-49.

Arellano, M., and S. Bond (1991), "Some Tests of Specification for Panel Data: Monte Carlo Evidence and an Application to Employment Equations," Review of Economic Studies, 58, 277-297.

Arellano, M., and O. Bover (1995), "Another Look at the Instrumental-Variable Estimation of Error-Components Models," Journal of Econometrics, 68, 29-52.

Atje, R., and B. Jovanovic (1993), "Stock Markets and Development,” European Economic Review, Vol. 37, 632640. 
Beck, T., and R. Levine (2003), “Stock Markets, Banks, and Growth: Panel Evidence,” Journal of Banking and Finance, forthcoming.

Beck, T., R. Levine, and N. Loayza (2000), "Finance and the Sources of Growth,” Journal of Financial Economics, 58, 261-300.

Bekaert, G., C.R. Harvey, and C. Lundblad (2003), “Does Financial Liberalization Spur Growth?” Working Paper, Fuqua School of Business, Duke University, Durham, NC, USA.

Bernanke and Gertler (1990), "Financial Fragility and Economic Performance," Quarterly Journal of Economics, Vol. 55, 87-114.

Calderon, C., A. Chong, and N. Loayza (2000), "Determinants of Currenr Account Deficits in Developing Countries," World Bank Research Policy Working Paper 2398.

Caporale, G.M., and N. Pittis (1997), "Causality and Forecasting in Incomplete Systems,” Journal of Forecasting, Vol. 16, 425-437

Cho, Y.J. (1986), "Inefficiencies from Financial Liberalization in the Absence of Well-Functioning Equity Markets," Journal of Money, Credit, and Banking, Vol. 18, 191-199.

Dailami, M., and M. Atkin (1990), "Stock Markets in Developing Countries: Key Issues and A Research Agenda," Policy Research and External Affairs Working Papers, The World Bank.

Demetriades, P., and K. Hussein (1996), "Does Financial Development Cause Economic Growth: Time-Series Evidence from 16 Countries," Journal of Development Economics, Vol. 51, 387-411.

Demirguc-Kunt, A. (1994), "Developing Country Capital Structure and Emerging Stock Markets," Policy Research Working Paper, WPS 933, July.

Demirguc-Kunt, A., and R. Levine (1995), "Stock Markets, Corporate Finance, and Economic Growth: An Overview," Working Paper, World Bank, No 1389.

EMDB (1998), "Emerging Markets Data Base," International Finance Corporation (IFC), Washington D.C.

Engle, R.F. (1982), "Autoregressive Conditional Heteroscedasticity with Estimates of the Variance of United Kingdom Inflation,” Econometrica, 50, 987-1008.

Goldsmith, R.W. (1969), "Financial Structure and Development," New Haven, Yale University Press.

Gurley, J., and E. Shaw (1955), "Financial Aspects of Economic Development," American Economic Review, Vol. 45, 515-537.

International Financial Statistics (1998), “International Financial Statistics Year Book,” International Monetary Fund (IMF), Washington D.C.

Kumar, M.S., and R. Feldman. (1995), "Emerging Equity Markets: Growth, Benefits, and Policy Concerns," Working Paper, World Bank, Vol. 10, 181-200.

Levine, R., and S.J. Zervos (1993), "What We Have Learned about Policy and Growth from Cross-country Regressions?" American Economic Review, Vol. 83, 426-430.

Alfaro, Laura, Sebnem Kalemli-Ozcan, and Vadym Volosovych. 2008. "Why Doesn't Capital Flow from Rich to Poor Countries? An Empirical Investigation”. Review of Economics and Statistics, 90(2), pp. 347-368.

Arcand, J.L., E. Berkes, and U. Panizza. 2015. “Too Much Finance?” Journal of Economic Growth, Volume 20, Issue 2, pp. 105-148.

Beck, Thorsten, Hans Degryse, and Christiane Kneer. 2014. "Is More Finance Better? Disentangling Intermediation and Size Effects of Financial Systems". Journal of Financial Stability, Volume 10 (February), pp. 50-64

Chinn, M., and H. Ito. 2007. "Current Account Balances, Financial Development and Institutions: Assaying the World 'Savings Glut'.” Journal of International Money and Finance, Volume 26, Issue 4, p. 546-569 (June)

Chinn, M., and H. Ito. 2006. "What Matters for Financial Development? Capital Controls, Institutions, and Interactions.” Journal of Development Economics, Vol. 82, pp. 163-192.

Chinn, M., B. Eichengreen, and H. Ito. 2014. "A Forensic Analysis of Global Imbalances,” Oxford Economic Papers 66 (2): 465-490.

Dabla-Norris, Era, and Narapong Srivisal. 2013. "Revisiting the Link between Finance and Macroeconomic Volatility". IMF Working Paper 13/29. Washington: International Monetary Fund (January).

Demirgüç-Kunt, Asli, and Harry Huizinga. 2001. "Financial Structure and Bank Profitability". Asli DemirgüçKunt and Ross Levine, eds. Financial Structure and Economic Growth, Cambridge: MIT Press.

Demirgüç-Kunt, Asli, and Harry Huizinga. 2010. "Bank Activity and Funding Strategies: The Impact on Risk and Returns". Journal of Financial Economics, 98, pp. 626-650.

Edison, H. J., M.W. Klein, L. Ricci, and T. Sløk. 2004. "Capital Account Liberalization and Economic Performance: Survey and Synthesis”. IMF Staff Papers, 51(2), pp. 220-256. Washington, DC: International Monetary Fund

Edwards, S., 1996. "Why Are Latin America's Saving Rates So Low?: An International Comparative Analysis". Journal of Development Economics, Vol. 51.

Hasan, Iftekhar, Michael Koetter, and Michael Wedow. 2009. "Regional growth and finance in Europe: Is there a 
quality effect of bank efficiency?” Journal of Banking and Finance, 33, pp. 1446-1453.

Henry, P.B. 2006. "Capital Account Liberalization: Theory, Evidence, and Speculation".

NBER Working Paper No. 12698. Cambridge: National Bureau of Economic Research. Johnson, S., J. McMillan, and C. Woodruff. 2002. "Property Rights and Finance." American Economic Review, 92, pp. 1335-1356.

King, R.G., and R. Levine. 1993. "Finance and Growth: Schumpeter Might Be Right". Quarterly Journal of Economics, 108, pp. 717-738.

Kose, M. A., E. Prasad, K. Rogoff, and S. J. Wei. 2006. "Financial Globalization: A Reappraisal”. IMF Working Paper 06/189. Washington, DC: International Monetary Fund.

Kose, M. Ayhan, Eswar S. Prasad, and Ashley D. Taylor. 2011. "Thresholds in the Process of International Financial Integration”. Journal of International Money and Finance, Vol. 30(1) (February), pp. 147-179.

Lane, P., and G.M. Milesi-Ferretti. 2001. "The External Wealth of Nations: Measures of Foreign Assets and Liabilities for Industrial and Developing Countries". Journal of International Economics, 55, pp. 263-294.

Lane, P., and G.M. Milesi-Ferretti. 2007. "The External Wealth of Nations Mark II: Revised and Extended Estimates of Foreign Assets and Liabilities, 1970-2004”. Journal of International Economics, 73(2), pp. 223250.

Lane, Philip R., and Gian Maria Milesi-Ferretti. 2017. "International Financial Integration in the Aftermath of the Global Financial Crisis”. IMF Working Paper WP/17/115. Washington, D.C.: International Monetary Fund.

Levine, Ross. 2005. "Finance and Growth: Theory and Evidence". In Philippe Aghion and Steven Durlauf, eds., Handbook of Economic Growth, Edition 1, Volume 1, Chapter 12, Elsevier, pp. 865-934.

Levine, Ross. 1998. "Stock Markets, Banks, and Economic Growth". American Economic Review, 88, pp. $537-$ 558. 